\title{
Influence of mutation induction on the chemical composition of cowpea Vigna unguiculata (L.) Walp
}

\author{
Olabisi F. Adekola* and Funsho Oluleye \\ Department of Agronomy, University of Ilorin, llorin, Nigeria. \\ Accepted 9 August, 2007
}

\begin{abstract}
Cowpea is one of the major sources of plant protein in Nigeria. The nutritional value of cowpea has long been recognized in Africa. This study was conducted to examine the influence of mutation induction on nutritional quality of cowpea. Dry sample of cowpea 'IT84S 2246 D' mutants and the non irradiated parent were ground to fine powder and used for proximate analyses in three experiments. Data were collected on dry weight basis on crude fat, crude fibre, crude protein, tannin, dry matter, moisture content and ash content. Results from the proximate analysis showed significant variation between the plant types for all parameters except crude fibre content. Mutant 7 which has the highest protein content $(31.06 \%)$ and the least ash content $(3.50 \%)$ and mutant 14 which has high dry matter $(95.06 \%)$ and the least moisture content $(4.91 \%)$ are much better than the parent. They are therefore recommended for inclusion in cowpea breeding program for improved seed quality. Crude protein content was significantly negatively correlated with ash and tannin contents. These are indices of improved seed quality in cowpea mutants.
\end{abstract}

Key words: Cowpea, mutants, proximate analyses, nutritional composition.

\section{INTRODUCTION}

Cowpea, Vigna unguiculata (L.) Walp, is an important food legume crop in Africa. It is one of the five recognized sub-species cultivated in the genus Vigna, and the most widespread and economically important (Summerfield et al., 1974). The economic and nutritional value of cowpea to man has long been recognized in Africa (Aykroyd and Doughty, 1964). It is an important source of inexpensive protein and calories for many people in the semi-arid areas of West and Central Africa. Their high protein and lysine contents make them a natural supplement to staple diets of cereals, roots and tubers commonly grown in many poor countries (Bressani, 1985). All the plant parts of cowpea used for food are nutritious, providing 23 to $25 \%$ protein, vitamins and minerals. It is a high value crop, contributing significantly to farmer's income in most rural societies (Ogunwolu, 1990).

Grain legumes are found to be well suited for genetic improvement through mutation breeding due to their evolutionary selection history (IAEA, 1977). It has been

\footnotetext{
*Corresponding author. E-mail: fatimoadekola@yahoo.co.uk.
}

shown that most legumes have lost many alleles for high productivity, seed quality, pest and diseases resistance in the process of adaptation to environmental stress. Valuable progress has been reported on the improvement of nutritional quality of some legumes by mutation induction. IAEA (1977) reported the development of enhanced lysine content from two commercial barley cultivars 'Bomi' and 'Calsberg II'. IAEA (1991) reported the successful use of induced mutation to improve the qualitative character in soybean. Soybean mutants $\mathrm{C}_{3}$ and $\mathrm{C}_{9}$ with improved oil and protein contents were developed from parent cultivar ' 'Calland' and 'Amsoy-71' through gamma irradiation.

The nutritive potential of some cowpea varieties have been examined by Alector and Aladetimi (1989) with respect to proximate chemical composition, mineral content and some endogenous toxic constituents. Significant intra varietal differences exist with respect to mineral content and anti nutritional components of cowpea. However, information on the effect of mutation induction on cowpea nutritional composition is very scanty. By inducing mutation in cowpea, it may be possible to develop new germplasms having improved nutritional quality 
Table 1. Mean nutritive values of putative mutants obtained by proximate analysis.

\begin{tabular}{|c|c|c|c|c|c|c|c|}
\hline Plant type & $\begin{array}{l}\text { Crude } \\
\text { fat (\%) }\end{array}$ & $\begin{array}{c}\text { Crude } \\
\text { fibre (\%) }\end{array}$ & $\begin{array}{c}\text { Crude } \\
\text { protein (\%) }\end{array}$ & $\begin{array}{c}\text { Dry } \\
\text { matter (\%) }\end{array}$ & $\begin{array}{c}\text { Moisture } \\
\text { content (\%) }\end{array}$ & $\begin{array}{c}\text { Tannin } \\
\text { content (\%) }\end{array}$ & $\begin{array}{c}\text { Ash } \\
\text { content (\%) }\end{array}$ \\
\hline Mutant 1. & $4.33^{\mathrm{a}^{*}}$ & 1.03 & $22.00^{\mathrm{h}}$ & $94.51^{\mathrm{cd}}$ & $5.48^{\text {efg }}$ & $10.70^{b}$ & $5.40^{\mathrm{a}}$ \\
\hline Mutant 2. & $3.58^{c}$ & 1.38 & $28.15^{c}$ & $94.90^{\mathrm{abc}}$ & $5.17^{\mathrm{h}}$ & $5.44^{\text {efg }}$ & $5.03^{a}$ \\
\hline Mutant 3. & $2.62^{g h}$ & 1.67 & $26.16^{d}$ & $95.35^{a}$ & $5.71^{\text {de }}$ & $4.48^{i}$ & $4.35^{\mathrm{bcd}}$ \\
\hline Mutant 4. & $2.48^{g h}$ & 3.95 & $28.17^{c}$ & $93.50^{\mathrm{gh}}$ & $6.50^{a b}$ & $5.13^{g h}$ & $3.97^{d}$ \\
\hline Mutant 5. & $2.60^{\mathrm{gh}}$ & 1.87 & $16.04^{\prime}$ & $94.70^{\mathrm{bcd}}$ & $5.30^{\mathrm{gh}}$ & $6.05^{d}$ & $5.20^{a}$ \\
\hline Mutant 6. & $4.22^{a}$ & 1.77 & $30.12^{b}$ & $93.42^{g h}$ & $6.54^{\mathrm{ab}}$ & $6.41^{\mathrm{c}}$ & $5.42^{a}$ \\
\hline Mutant 7. & $2.48^{g h}$ & 2.45 & $31.06^{a^{*}}$ & $93.49^{g h}$ & $6.26^{b c}$ & $5.22^{\text {fgh }}$ & $3.50^{\mathrm{e}^{*}}$ \\
\hline Mutant 8. & $2.40^{\mathrm{h}}$ & 1.67 & $28.11^{c}$ & $94.24^{\text {def }}$ & $5.79^{d}$ & $4.89^{h}$ & $4.10^{\mathrm{cd}}$ \\
\hline Mutant 9. & $3.17^{d}$ & 1.92 & $28.21^{c}$ & $93.75^{\mathrm{fgh}}$ & $6.35^{b c}$ & $5.5 \mathrm{ef}$ & $4.00^{d}$ \\
\hline Mutant 10. & $2.47^{\mathrm{h}}$ & 3.30 & $25.54^{e}$ & $93.87^{\text {efg }}$ & $6.17^{c}$ & $5.15^{\mathrm{gh}}$ & $5.10^{a}$ \\
\hline Mutant 11. & $3.92^{b}$ & 1.72 & $25.56^{\mathrm{e}}$ & $94.47^{\mathrm{cd}}$ & $5.42^{\mathrm{fgh}}$ & $5.60^{e}$ & $4.45^{b c}$ \\
\hline Mutant 12. & $3.05^{\mathrm{de}}$ & 1.22 & $25.98^{d}$ & $94.47^{\mathrm{cd}}$ & $5.45^{\text {efg }}$ & $6.17^{\mathrm{cd}}$ & $4.63^{b}$ \\
\hline Mutant 13. & $2.70^{\mathrm{fg}}$ & 1.62 & $24.50^{f}$ & $93.63^{\mathrm{gh}}$ & $6.30^{b c}$ & $6.08^{d}$ & $5.27^{a}$ \\
\hline Mutant 14. & $2.70^{\mathrm{fg}}$ & 1.43 & $25.98^{d}$ & $95.06^{a b^{*}}$ & $4.91^{\mathrm{i}^{*}}$ & $4.53^{i}$ & $4.40^{\mathrm{bcd}}$ \\
\hline Mutant 15. & $3.85^{b}$ & 2.07 & $27.88^{c}$ & $94.30^{\mathrm{de}}$ & $5.65^{\text {def }}$ & $5.33^{\text {efg }}$ & $5.05^{a}$ \\
\hline (Parent) 16. & $3.73^{b c}$ & 1.13 & $24.31^{f}$ & $93.27^{\mathrm{h}}$ & $6.67^{a}$ & $3.32^{j}$ & $4.20^{\mathrm{cd}}$ \\
\hline S.E & 0.1 & 2.2 & 0.1 & 0.1 & 0.1 & 0.1 & 0.1 \\
\hline
\end{tabular}

Means with different letter(s) within column are significantly different at 0.05 level of probability.

*Better than the parent.

and reduced endogenous toxic constituents. This study thus aims at evaluating the effect of mutation induction on the nutritive values of cowpea and examining if changes in nutritional components are desirable or detrimental.

\section{MATERIALS AND METHODS}

\section{Seed treatment}

Cowpea 'IT84S2246D' seeds were exposed to gamma irradiation at the Centre for Energy Research and Development, Obafemi Awolowo University, Ile-lfe (Nigeria). The seeds were treated with a dose of 245Gy which is the optimum dose for the cultivar used at the rate of $24 \mathrm{~Gy} / \mathrm{min}$ (Adekola and Awoleye, 2002). Mutants were selected from among the $\mathrm{M}_{2}$ generation plants based on visible changes in plant architecture from the parent (Adekola, 2005). Mutants were carried to $\mathrm{M}_{4}$ generation and seeds were subjected to proximate analyses.

\section{Sample preparation}

For the series of analyses carried out in this study, $200 \mathrm{~g}$ of the dry seeds of each plant sample were ground to fine powder. They were kept in tightly closed containers and stored in the refrigerator before analyses.

\section{Proximate analyses of seeds of mutants}

Proximate analyses of seeds of the mutants were carried out as described by AOAC (1990). The following physico-chemical parameters were carried out in three experiments: Moisture content, dry matter content, ash content, crude protein, crude fat and crude fibre contents. Tannin content was determined according to the method of Joslyn (1970).

\section{Data analysis}

Data were subjected to analysis of variance using the SPSS software package. Significant means obtained were separated by the use of Duncan's Multiple Range Test. Correlation analysis was also carried out to evaluate associations between parameters.

\section{RESULTS AND DISCUSSION}

Results on mean nutritive value of mutants obtained by proximate analyses are presented in Table 1. Percentage crude fat ranged between 2.40 and $4.33 \%$. The parent has $3.37 \%$ crude fat content. The highest crude fat content $(4.33 \%)$ was observed in mutant 1 while the least $(2.40 \%)$ was found in mutant 8 . Significant differences occurred among the plant types for this parameter at $p=$ 0.05 (Table 2). Crude fat content that ranged between 1.14 and $3.03 \%$ has been reported by Onwuliri and Obu (2002) for some commercial cowpea varieties. Alector and Aladetimi (1989) reported an average of $5.9 \%$ crude fat for cowpea. The crude fat content of mutants obtained in this study compares favourably with those obtained in commercial varieties.

Percentage crude fibre was between 1.03 and $3.95 \%$. The parent has $1.13 \%$ crude fibre content, mutant 4 had the highest $(3.95 \%)$ while the least $(1.03 \%)$ was found in mutant 1. Crude fibre of between 1.7 and $4.5 \%$ was reported by Onwuliri and Obu (2002). However, no significant difference was observed among the plant types at $p=0.05$. Protein content ranged from 16.04 to $31.06 \%$. The parent has $24.31 \%$ crude protein. Mutant 7 
Table 2. Mean squares (MS) from analysis of variance of nutritive values obtained from proximate analysis of the seeds.

\begin{tabular}{|l|c|c|c|c|c|c|c|c|}
\hline $\begin{array}{l}\text { Source of } \\
\text { Variation }\end{array}$ & D.F & $\begin{array}{c}\text { MS Crude } \\
\text { fat (\%) }\end{array}$ & $\begin{array}{c}\text { MS Crude } \\
\text { fibre (\%) }\end{array}$ & $\begin{array}{c}\text { MS Crude } \\
\text { Protein (\%) }\end{array}$ & $\begin{array}{c}\text { MS Dry } \\
\text { matter (\%) }\end{array}$ & $\begin{array}{c}\text { MS Moisture } \\
\text { content (\%) }\end{array}$ & $\begin{array}{c}\text { MS Tannin } \\
\text { content (\%) }\end{array}$ & $\begin{array}{c}\text { MS Ash } \\
\text { content (\%) }\end{array}$ \\
\hline Plant type & 16 & $1.338^{\star}$ & $18.388 n . S$ & $35.734^{\star}$ & $1.214^{*}$ & $0.878^{*}$ & $12.52^{*}$ & $1.107^{\star}$ \\
Replication & 2 & 0.012 & 14.815 & 0.00297 & 0.0621 & 0.00148 & 0.108 & 0.0401 \\
Error & 32 & 0.015 & 13.989 & 0.0359 & 0.0908 & 0.0235 & 0.0344 & 0.0538 \\
Total & 51 & & & & & & & \\
\hline
\end{tabular}

*Significant at 0.05 level of probability; n.s = not significant.

had the highest crude protein content $(31.06 \%)$ while mutant 5 had the least (16.04\%). Significant differences were observed among the plant types for this trait at $p=$ 0.05 . An average crude protein content of between 20.5 and $31.7 \%$ has been reported by Onwuliri and Obu (2002) for some commercial cowpea varieties. The higher protein content found in mutant 7 as compared with the parent signifies the importance of mutation induction in cowpea improvement.

Percentage dry matter content ranged between 93.27 and $95.35 \%$. The parent had the least dry matter content $(93.27 \%)$ while mutants 3 and 14 recorded the highest (95.35 and $95.06 \%$, respectively). Moisture content was between 4.91 and $6.67 \%$. The parent had the highest moisture content $(6.67 \%)$ while mutant 14 recorded the least $(4.91 \%)$. Plant type was found to have significant effect on these traits at $p=0.05$. Onwuliri and Obu (2002) obtained seed moisture content of between 6.2 and $8.92 \%$ for cowpea. This is much higher than the values obtained for the mutants as indicated above. Low moisture content in cowpea seeds is very important for its durability in storage.

Percentage tannin content was between 3.32 and $10.70 \%$. Mutant 1 had the highest value while the least $(3.32 \%)$ was recorded for the parent. Significant differences were observed between plant types for this trait at $p=0.05$. Ash content ranged from $3.50 \%$ to $5.42 \%$. Mutant 7 recorded the least ash content $(3.50 \%)$ while mutant 6 had the highest $(5.42 \%)$. Significant differences were found among the plant types for these traits at $p=0.05$.

Significant differences observed for the various nutritive values among the mutants are indications of significant genotypic differences induced by gamma irradiation. Alector and Aladetimi (1989) obtained significant varietal differences for ether soluble crude fat in cowpea. Fawole (1999) has also reported significant genetic variability for protein, fat and iron contents in fifty-two cowpea varieties. From the results of this study therefore, genetic improvement of the total nutritive values could be possible in cowpea through gamma irradiation.

Mutant 7 had several advantages over the parent and these include higher protein content $(31.06 \%)$ and the least ash content, which indicate higher digestibility. Mutant 14 had the least moisture content $(4.91 \%)$, least tannin content $(4.53 \%)$ and high dry matter content
(95.06\%). This mutant may probably be more durable in storage because of its' low moisture content and high dry matter. It also has the least tannin content among the mutants, which may possibly makes it more digestible and less toxic. Legume seed proteins have been extensively studied for their economic importance, since they provide the bulk of proteins consumed by humans and livestock. Alector and Aladetimi (1989) reported that cowpea variety contained on the average $22.5 \%$ crude protein. Onwuliri and Obu (2002) also reported crude protein content of between 20.5 and $31 \%$ for some northern Nigerian cowpea varieties.

Mutant 7 and 14, which had 31.06 and $25.98 \%$ crude protein content respectively are much higher than an average cowpea variety. This improvement must have been acquired through mutation induction. The two mutants appeared to have good seed quality in terms of digestibility, storability and nutritional quality. They are therefore, considered as good materials for improvement of nutritional value in cowpea.

Results from series of correlations between the nutritive values (Table 3) show significant associations between them. These include moisture content which was negatively correlated with dry matter content $(r=-0.85)$, but positively correlated with crude protein $(r=0.31)$. Ash content was positively correlated with crude fat $(r=0.35)$ and tannin content $(r=0.57)$. Crude fat and crude fibre were negatively correlated $(r=-0.3)$ while crude protein was negatively correlated with tannin content $(r=-0.33)$ and ash content $(r=-0.45)$. Some of these associations have been previously reported in cowpea. Baker et al. (1989) reported similar significant positive correlations between ash content and protein. Crude fat was negatively correlated with protein at $p=0.05$. Such character associations could serve as useful selection indices for cowpea improvement.

\section{Conclusion}

Significant genetic variability was created among the putative mutants with respect to their chemical components. This is an indication of possibility for improvement of cowpea seed quality through induced mutation. Non desirable quality such as those that makes the seeds less digestible and anti nutritive content were greatly reduced 
Table 3. Correlation between nutritive values of seeds of gamma induced putative mutants and parent.

\begin{tabular}{|l|c|c|c|c|c|c|c|}
\hline Nutritive value & Moisture & Dry matter & Crude fat & Total ash & Crude protein & Crude fibre & Tannin \\
\hline Moisture & 1 & -0.85 & -0.05 & -0.15 & $0.31^{*}$ & 0.11 & -0.02 \\
Dry matter & & 1 & -0.02 & 0.07 & -0.26 & -0.10 & -0.06 \\
Crude fat & & & 1 & $0.35^{*}$ & 0.04 & $-0.3^{*}$ & 0.26 \\
Total ash & & & & 1 & $-0.45^{\star *}$ & -0.15 & $0.57^{\star *}$ \\
Crude protein & & & & & 1 & 0.14 & $-0.33^{*}$ \\
Crude fibre & & & & & & 1 & -0.09 \\
Tannin & & & & & & 1 \\
\hline
\end{tabular}

${ }^{*}$ Correlation is significant at $p=0.05 ;{ }^{* *}$ correlation is significant at $p=0.01$.

in some mutants while good characters such as enhanced protein content and low moisture content were observed. Significant negative correlations were observed between total ash content and protein content. This is an indication of improved safety of cowpea mutants with enhanced protein content, since most of the toxic elements form the ash content. It could also lead to breeding of cowpea with enhanced dietary protein for the people.

\section{REFERENCES}

Adekola OF (2005). Tolerance of cowpea mutants to the legume pod borer, Maruca vitrata Fabricius (Lepidoptera : Pyralidae) Ph.D Thesis, Department of Agronomy, University of Ilorin; Ilorin, Nigeria. pp. 104116.

Adekola OF, Awoleye F (2002). Radio sensitivity of three cowpea cultivars to gamma irradiation, Faculty of Science, University of Ilorin, Nigeria. Niger. J. Pure Appl. Sci. 17: 1182-1187.

Alector VA, Aladetimi OO (1989). Compositional evaluation of some cowpea varieties and some under utilized edible legumes in Nigeria. Nahrung, 33(10): 999-1007.

AOAC (1990). Official methods of analysis. $15^{\text {th }}$ edition, Association of official analytical chemists Inc., Arlington, Virginia, USA, p. 1094.

Aykroyd NK, Doughty J (1964) Legumes in human diet. FAO of the United Nations, Rome, Italy, p. 112.

Baker TA, Nielsen SS, Shade RE, Singh BB (1989). Physical and chemical attributes of cowpea lines resistant and susceptible to Callosobruchus maculatus (F.) (Coleoptera: Bruchidae) J. Stored Prod. Res. 25(1): 1-8.

Bressani R (1985). Nutritive value of cowpea. In cowpea research, production and utilization, edited by Singh SR, Rachie KO, John wiley and sons, U.K. pp. 353-359.

Fawole I (1999). Genetics and Increased Cowpea production in Nigeria in : Genetics and Food security in Nigeria. pp. 77-81
IAEA (1977). Manual on mutation breeding, $2^{\text {nd }}$ edition, Technical report series, No. 119, International Atomic Energy Agency, Vienna, Austria. pp. 1-285.

IAEA (1991). Improvement of basic food crops in Africa through plant breeding including the use of induced mutation. Report of the second research co-ordination meeting for the $\mathrm{FAO} / \mathrm{IAEA} /$ /taly project, held at Dar es Salam, Tanzania, $3-7^{\text {th }}$ june 1991. IAEA, Vienna, Austria. pp. 109.

Joslyn MA (1970). Methods in food analysis, Academic press, London, p. 845.

Ogunwolu EO (1990). Damage to cowpea by the legume pod borer, Maruca testulalis geyer, as influenced by infestation density in Nigeria. Trop. Pest Manag. 36(2): 138-140.

Onwuliri VA, Obu JA (2002). Lipids and other constituents of Vigna unguiculata and Phaseolus vulgaris grown in northern Nigeria. Food Chem. 78(1): 1-7.

Summerfield RJ, Huxley PA, Steele WM (1974). Cowpea (Vigna unguiculata L. walp) Field Crop Abstract 27: 301-312. 